\title{
Characteristic and evaluation of sustainability artisanal bonito (Auxis spp.) fisheries in the Prigi Bay and surrounding waters
}

\author{
Arief Wujdi ${ }^{1, *}$, Bram Setyadji ${ }^{1}$, Hety Hartaty ${ }^{1}$, Ririk Kartika Sulistyaningsih ${ }^{1}$ \\ ${ }^{1}$ Research Institute for Tuna Fisheries, Denpasar, Bali, Indonesia - 80224
}

\begin{abstract}
Bonito plays an important role as the main ingredient for marinated products and provides a livelihood for coastal communities. Given the emergence of Indonesia's over-exploited small-scale marine fisheries resources, this study aims to characterize and evaluate fishery's sustainability based on bioeconomic analyses. Time series catch and effort data were collected from 2005 to 2019 provided by Archipelagic Fishing Port of Prigi. Five surplus production models were also employed to generate catch-and-effort-based biological parameters, namely intrinsic growth rate (r), catchability (q), and carrying capacity (K). By adding economy parameters such as cost and price, the sustainability of catch and effort was also estimated at three management conditions. The catch abundance was peaked in April and September, characterized by the lack of rain. The CPUE was varied inter-annually. However, it declined during the last decade, indicating that the stock size was decreased. Although the average catches from 2015-2019 (9,984 tons) are lower than $\mathrm{C}_{\mathrm{MSY}}(11,695$ tons). However, the effort in 2019 (15,239 trips) has exceeded $\mathrm{E}_{\mathrm{MEY}}(14,237$ trips). Hence, reducing fishing efforts or maintaining it at E2018 level was suggested as a precaution to keep the fishery's sustainability and simultaneously generate optimum profit.
\end{abstract}

\section{Introduction}

One of the economically essential fisheries resources is bonitos (Auxis spp.), the main ingredient of marinated fish products. It can be found in almost all tropical and subtropical waters with an optimum temperature range between $27-27.9^{\circ} \mathrm{C}[1,2]$. Bonitos were also categorized into the neritic tuna group inhabiting in the water column between the surface and 50 meters depths [3-5], so that accessible by nets fishing, includes purse seine, gill net, Danish seine, and lift net [6]. In the Indian Ocean alone, the annual catches increased steadily from 106,145 tons in 2016 to 123,777 tons in $2018(\approx 16 \%)$, which more than $90 \%$ of the total bonito catch was contributed by six countries, namely Indonesia, India, Sri Lanka, Pakistan, and Iran [6].

The state owns fisheries resources in many developing countries as representatives of public ownership. Therefore, the fisheries naturally are considered common property and can

\footnotetext{
*Corresponding author : ariefwujdi@kkp.go.id
} 
be widely accessed by the public. In Indonesia, fisheries are managed by the government incorporating local wisdom and customary rules that are well-established in the community. In this management regime, the people have equal rights to access the resources in order to get the maximum benefit [7]. These conditions cause an increased investment in terms of the fishing unit includes new boats, fishing gears, engines, laborers, etc., and it threatens the stock healthiness [8-10]. It may also have impacted the local economy around the coastal area [8-9]. Therefore, an evaluation of the stock sustainability is urgently needed regularly to ensure that the fishing pressure does not exceed the resource carrying capacity. At the same time, the fishers can utilize it to obtain an optimum economic benefit for the long-term period [11-12].

Several attempts on the stock assessment of pelagic resources have been conducted in Indonesian waters using the holistic and dynamic method. For instance, surplus production models, as part of the holistic model, are the most known to assess the stock and utilization level of skipjack [13-14] and other pelagic fishes [15]. It requires only catch and effort data from the single and multi-gear fishery, as well as single-and multi-species cases $[7,9,12]$. Therefore, this study aims to characterize the bonito fisheries and evaluate the optimum level of fisheries sustainability by applying surplus production models and bioeconomic analysis. It is expected that this research can provide a guideline to manage the fisheries resources effectively, both from a biology and economic perspective.

\section{Materials and methods}

\subsection{Data collection}

Data collection was conducted during field surveys as the case study at the Archipelagic Fishing Port of Prigi, Trenggalek Regency, East Java Province, from September to December 2020 (Fig 1). The fishing port has been chosen as one of the main landing bases for small pelagic fishes with high productivities in East Java [15-16]. Fishing activities were carried out on a one-day trip. Hence, we assumed that the fishing ground focused on the narrowranged area, and the fish abundance is well-represented by the data. The primary data was gathered using questionary-based interviews with the fishers to collect information related to the fishing activities, gear specifications, tactics, and cost unit. While secondary data consists of time series catch (in tons) and effort (in trips) from 2005 to 2019, from the monthly landing data monitored by the fishing port authority. The average fish price (in Rupiah) is also taken from annual statistic data [17-18] as an input for the bioeconomic analyses.

\subsection{Data analysis}

\subsubsection{Standardized fishing effort and seasonal abundance index}

Given that various fishing gears caught bonito resources whereas each fishing gear has different fishing power, the fishing effort was standardization. A standardized effort was the most effective fishing gear fishing indicated by a fishing power index equal to 1 (FPI=1) [14]. The FPI was calculated using a systematic formula by multiplying the FPI and observedfishing effort from each gear [19-20], as follow:

$$
\mathrm{FPI}=\frac{C P U E_{i}}{C P U E_{s t d}}
$$




$$
\mathrm{E}_{\mathrm{std}}=\mathrm{FPI} * \mathrm{E}_{\mathrm{i}}
$$

Where $E_{\text {std }}$ is the standardized fishing effort, $E_{i}$ is the fishing effort of gear-i, CPUE $E_{i}$ is the

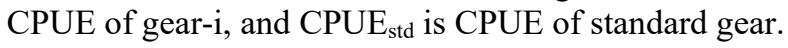

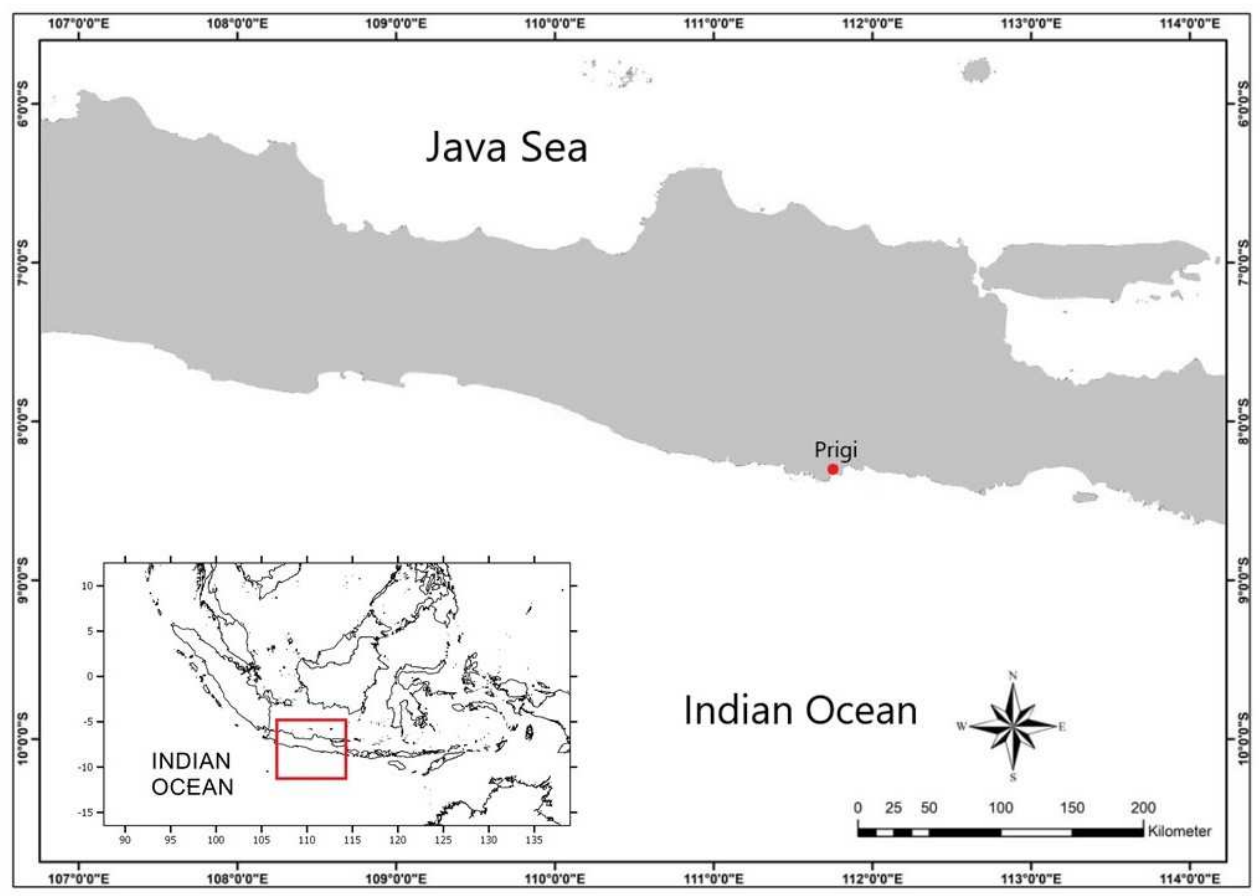

Fig. 1. Research location to evaluate bonito fishery status in the Prigi Bay and surrounding waters

The seasonal abundance index is determined using a monthly average percentage method based on the time series of CPUE [21], following the steps:

a. The calculation of the average monthly CPUE for each year from 2005 to 2019 use the

following formula:

$$
\overline{\mathrm{U}}=\frac{1}{m} \sum_{i=1}^{m} U i
$$

Where $\bar{U}$ is the average monthly CPUE in a year ( $\mathrm{kg} /$ trip), Ui is the monthly CPUE ( $\mathrm{kg} / \mathrm{trip})$, and $\mathrm{m}$ is the number of months in a year (12 months).

b. The calculation of the ratio (Up) between monthly CPUE (Ui) towards average monthly CPUE in a year $(\bar{U})$ in a percent:

$$
\mathrm{Up}=\frac{U_{i}}{\overline{\mathrm{U}}} \times 100 \%
$$

c. The calculation of fishing season indices (FS): 


$$
\mathrm{FS}_{\mathrm{i}}=\frac{1}{y} \sum_{i=1}^{y} U p
$$

The high abundance season was categorized when the value of $\mathrm{FS}_{\mathrm{i}}$ was higher than 1 $(100 \%)$. In contrast, if $\mathrm{FS}_{\mathrm{i}}$ is lower than $1(100 \%)$ means a low season has occurred. While $\mathrm{FS}_{\mathrm{i}}$ equal $1(100 \%)$ means the normal condition.

\subsubsection{Model selection and estimation of biological parameters}

Surplus production models are commonly used to investigate some biological parameters by deriving them from catch and effort data [22]. Five models were used in the study, namely the Schaefer [23], Fox [24], Schnute [25], Walter and Hilborn (WH), and Clarke Yoshimoto Pooley (CYP) model [26], to determine some biological parameters, namely intrinsic growth rate $(\mathrm{r})$, catchability $(\mathrm{q})$, and carrying capacity $(\mathrm{K})$. The Schaefer, Schnute, and Walter and Hilborn models are mostly known as the logistic model due to a logistic yield-effort curve being formed. Meanwhile, the Fox and CYP models have an exponential relationship and are also known as the Gompertz model [27]. Both logistic and exponential models are assumed on the steady-state relationship between stock size, fishing effort, and yield and were calculated using well-established equations [26] provided in Table 1. The best-fit model was selected for further analysis by relying on the value of the coefficient of determination $\left(\mathrm{R}^{2}\right)$ and the probability value of each independent variable. Then, the level of catch and effort for sustainable fisheries can be calculated based on a mathematical equation for logistic and exponential models.

Table 1. Some equations of the five surplus production models

\begin{tabular}{|c|c|c|}
\hline No & Model & Equation \\
\hline \multicolumn{3}{|r|}{ Logistic growth models } \\
\hline 1 & Schaefer & $(\mathrm{Un}+1-\mathrm{Un}-1 /(2 \mathrm{Un})=\mathrm{r}-(\mathrm{r} / \mathrm{qK})(\mathrm{Un})-\mathrm{q}(\mathrm{En})$ \\
\hline 2 & Schnute & $\ln (\mathrm{Un}+1 / \mathrm{Un})=\mathrm{r}-(\mathrm{r} / \mathrm{qK})((\mathrm{Un}+\mathrm{Un}+1) / 2)-\mathrm{q}((\mathrm{En}+\mathrm{En}+1) / 2)$ \\
\hline 3 & $\begin{array}{l}\text { Walter and } \\
\text { Hilborn }(\mathrm{WH})\end{array}$ & $(\mathrm{Un}+1-\mathrm{Un}-1)-1=\mathrm{r}-(\mathrm{r} / \mathrm{qK}) \mathrm{Un}-\mathrm{qEn}$ \\
\hline \multicolumn{3}{|r|}{ Exponential growth models } \\
\hline 4 & Fox & $(\mathrm{Un}+1-\mathrm{Un}-1) /(2 \mathrm{Un})=\mathrm{r} \ln (\mathrm{qK})-\mathrm{r} \ln (\mathrm{Un})-\mathrm{q}(\mathrm{En})$ \\
\hline 5 & $\begin{array}{l}\text { Clarke } \\
\text { Yoshimoto } \\
\text { Pooley (CYP) }\end{array}$ & $\ln (\mathrm{Un}+1)=(2 \mathrm{r} /(2+\mathrm{r})) \ln (\mathrm{qK})]+((2-\mathrm{r}) /(2+\mathrm{r})) \ln (\mathrm{Un})-(\mathrm{q} /(2+\mathrm{r}))(\mathrm{En}+\mathrm{En}+1)$ \\
\hline
\end{tabular}

\subsubsection{Bioeconomic analyses}

The bioeconomic analysis is an effort to combine biological parameters and economic factors (such as cost and price) to determine fishery conditions through a model [28]. However, involving economic factors in a surplus production model results in a higher level of complexity. Therefore, an assumption of a constant price and fishing cost was used in this study, so that a mathematic equation was developed [7-8], as follow:

$$
\begin{aligned}
& \pi=\mathrm{TR}-\mathrm{TC} \\
& \pi=\mathrm{p} * \mathrm{~h}-\mathrm{c} * \mathrm{E}
\end{aligned}
$$

Where $\pi$ is the net profit or economic rent (in Rupiah), TR is total revenue (in Rupiah), TC is the total cost (in Rupiah), $\mathrm{p}$ is the average of price (in Rupiah), his a total catch (kg), E is a fishing effort (trip), and $\mathrm{c}$ is the fishing cost (in Rupiah). Therefore, fishery sustainability 
can be estimated based on the ecological and economic perspective at three conditions of management, i.e., maximum sustainable yield (MSY), maximum economic yield (MEY), and open access (OA), as shown in Table 2 [22].

Table 2. The formula of fisheries sustainability indicators $(\mathrm{C}, \mathrm{E}$, and $\pi)$ at three conditions of management (MSY, MEY, and OA)

\begin{tabular}{|c|c|c|c|}
\hline \multicolumn{2}{|c|}{ Level } & Logistic model & Exponential model \\
\hline \multicolumn{2}{|c|}{ Catch (h) } & $\mathrm{qKE}(1-\mathrm{qE} / \mathrm{r})$ & $\mathrm{qKE} \exp ^{-(\mathrm{q} / \mathrm{r}) \mathrm{E}}$ \\
\hline \multirow[t]{3}{*}{ MSY } & $\mathrm{E}_{\mathrm{MSY}}$ & $\mathrm{r} / 2 \mathrm{q}$ & $\mathrm{r} / \mathrm{q}$ \\
\hline & $\mathrm{C}_{\mathrm{MSY}}$ & $\mathrm{rK} / 4$ & $\mathrm{qKE}_{\mathrm{MSY}} \exp ^{-(\mathrm{q} / \mathrm{r}) \mathrm{E}_{\mathrm{MSY}}}$ \\
\hline & $\pi_{\mathrm{MSY}}$ & $\mathrm{pC}_{\mathrm{MSY}}-\mathrm{cE}_{\mathrm{MSY}}$ & $\mathrm{pC}_{\mathrm{MSY}}-\mathrm{cE}_{\mathrm{MSY}}$ \\
\hline \multirow[t]{3}{*}{ MEY } & $\mathrm{E}_{\mathrm{MEY}}$ & $\mathrm{r} / 2 \mathrm{q}(1-\mathrm{c} / \mathrm{pqK})$ & $\mathrm{r} / \mathrm{q}\left[1-(\mathrm{c} / \mathrm{pqK}) \exp ^{\left.(\mathrm{q} / \mathrm{r}) \mathrm{E}_{\mathrm{MEY}}\right]}\right.$ \\
\hline & $\mathrm{C}_{\mathrm{MEY}}$ & $\mathrm{rK} / 4(1-(\mathrm{c} / \mathrm{pqK})(1+(\mathrm{c} / \mathrm{pqK})$ & $\mathrm{qkE}_{\mathrm{MEY}} / \exp \left(\mathrm{E}_{\mathrm{MEY}} \mathrm{q} / \mathrm{r}\right)$ \\
\hline & $\pi_{\mathrm{MEY}}$ & $\mathrm{pC}_{\mathrm{MEY}}-\mathrm{cE}_{\mathrm{MEY}}$ & $\mathrm{pC}_{\mathrm{MEY}}-\mathrm{cE} \mathrm{E}_{\mathrm{MEY}}$ \\
\hline \multirow[t]{3}{*}{$\mathrm{OA}$} & $\mathrm{E}_{\mathrm{OA}}$ & $\mathrm{r} / \mathrm{q}(1-\mathrm{c} /(\mathrm{pqk}))$ & $\mathrm{r} / \mathrm{q}[\ln (\mathrm{pqK})-\ln (\mathrm{c})]$ \\
\hline & $\mathrm{C}_{\mathrm{OA}}$ & $\mathrm{qKE}_{\mathrm{OA}}\left(1-\mathrm{qE} \mathrm{EA}_{\mathrm{OA}} / \mathrm{r}\right)$ & $\mathrm{qkE}_{\mathrm{OA}} \exp ^{-(\mathrm{q} / \mathrm{r}) \mathrm{E}_{\mathrm{OA}}}$ \\
\hline & $\pi_{\mathrm{OA}}$ & $\mathrm{pC}_{\mathrm{OA}}-\mathrm{cE}_{\mathrm{OA}}$ & $\mathrm{pC} \mathrm{C}_{\mathrm{OA}}-\mathrm{cE}_{\mathrm{OA}}$ \\
\hline
\end{tabular}

\section{Results}

\subsection{Fleet and fishing gear characteristics}

Bonito's landed catches in Prigi were caught dominantly by mini purse seines, followed by Danish seines, gill nets, troll lines, and hand lines. The mini purse seiner was characterized as a one-pair method that one fishing unit consists of two boats less than 30 gross tonnages (GT) in volume which was equipped by 140 to $160 \mathrm{hp}$ main engine. The fishing fleet operates at night on a daily basis without using fish-aggregated devices (FADs) to attract fish schooling.

The dimension of purse seine was commonly described in rectangular shapes ranging from $450-650 \mathrm{~m}$ in length and $50-60 \mathrm{~m}$ in depth. The central part of the mini purse seine consists of the wing, the main body, pocket, floats, lead weights, and rings. While, the ropes of the purse seine consist of a headline, float line, ground rope, sinker rope, and purse line. The Prigi-mini purse seiners are used to harvest small pelagic fishes so that the mesh size is $3 / 4$ inch on the main webbing (Fig 2).

\subsection{Trend of catch per unit of effort (CPUE) and seasonal abundance index}

The fishers based in Prigi Bay caught the bonito by using various fishing gears, resulting in different catchability for each fishing gear. Given that the mini purse seine has the highest effectivity to catch bonito indicated by the FPI $=1$, the CPUE was analyzed using standardized fishing efforts of the mini purse seine. The annual CPUE was varied interannually, with a decreasing trend shown during the last decade from $644 \mathrm{~kg} /$ trip in 2010 to $445 \mathrm{~kg} /$ trip in 2019. The decline of CPUE resulted from the high number of fishing efforts in each year, especially during 2013 until the current year, on the other hand, the catch fluctuated drastically (Fig. 3a). 


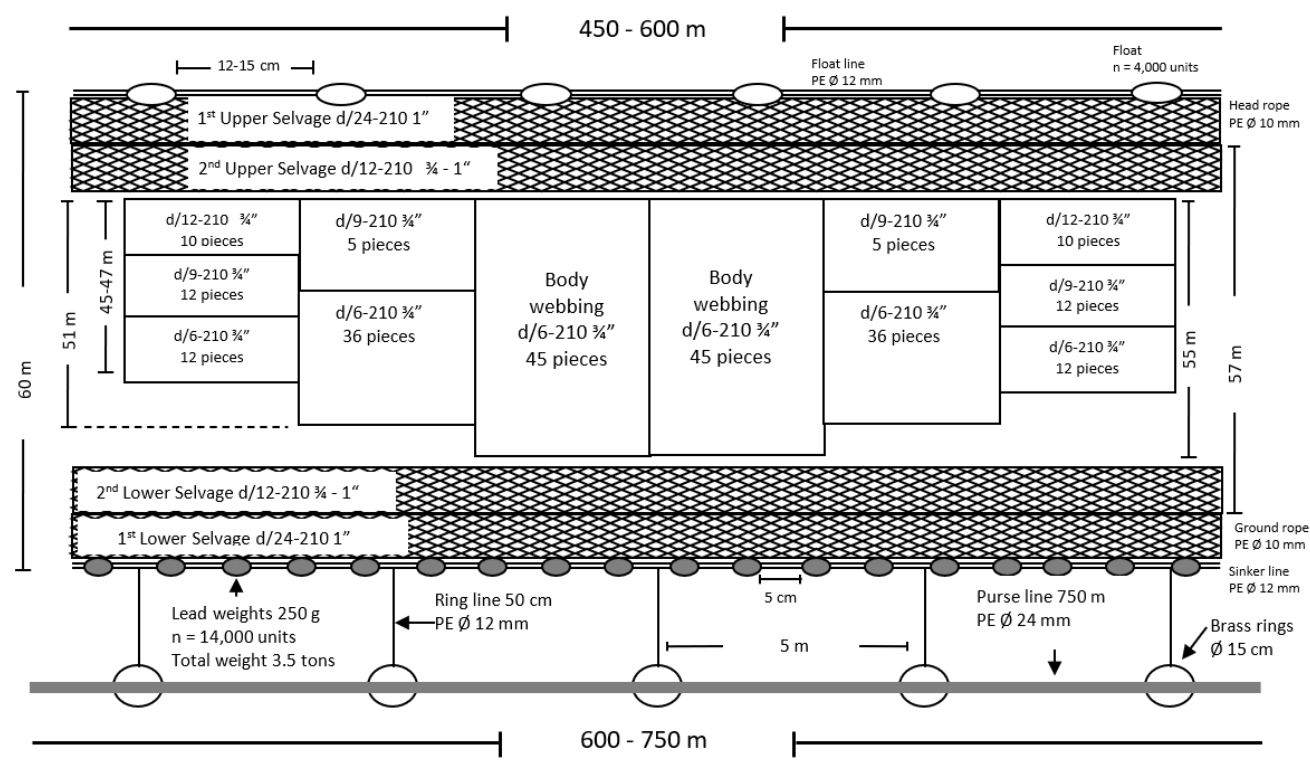

Fig. 2. Construction of mini purse seine to catch bonito and small pelagic resources in Prigi Bay and surrounding waters.

The average CPUE also showed a monthly variation, as shown in Fig 3b. The CPUE of bonito tends to be low during December and February or west monsoon characterized by a high frequency of rainfall. During this period, fishers prefer to repair their nets to prepare for the next $1^{\text {st }}$ transition season. Consequently, the monthly variation of CPUE results in an apparent seasonal pattern throughout the year. The abundance season of bonito peaked twice a year in April and September, which coincides with the $1^{\text {st }}$ and $2^{\text {nd }}$ transition periods (Fig $3 \mathrm{c})$.
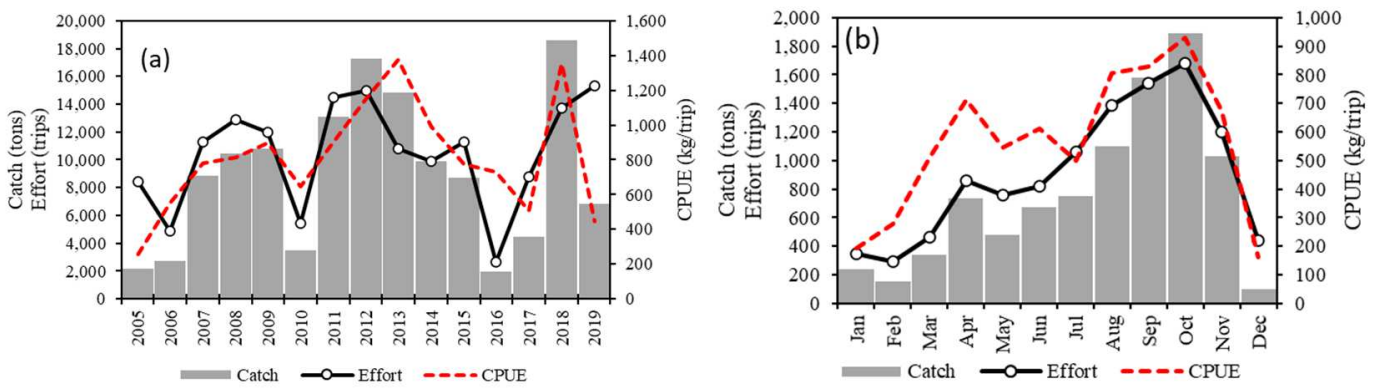


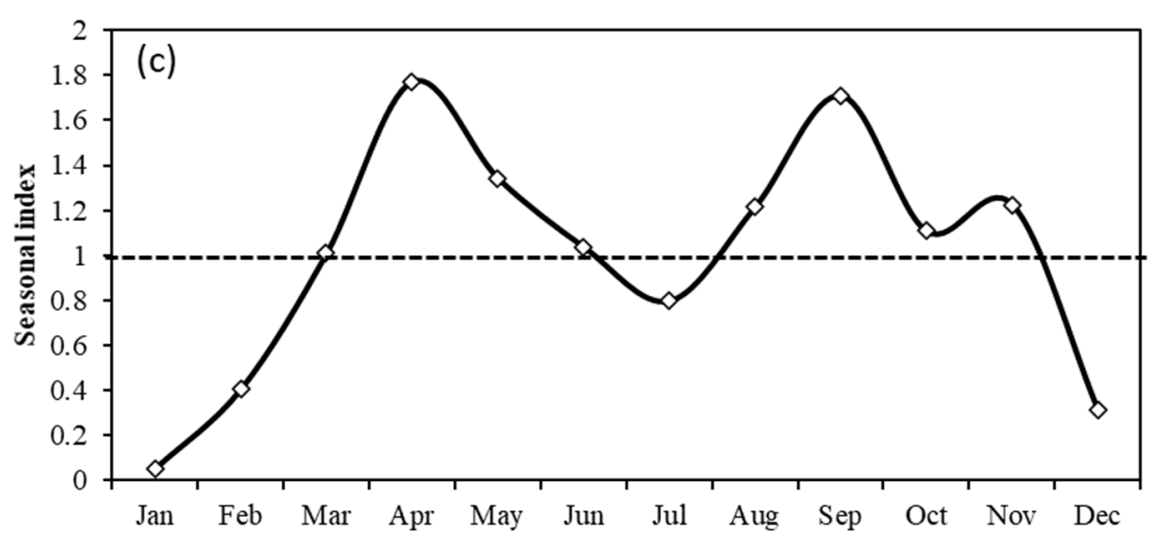

Fig. 3. The annual and monthly trend of the total catch, standardized fishing effort, and CPUE of bonito as illustrated in a and b, respectively, and seasonal abundance index throughout the year (c).

\subsection{Model selection and estimation of biological parameters}

The relationship between CPUE and the standardized-fishing efforts between 2005 and 2019 was plotted in model selection. It can be described as a linear and exponential equation with a similar coefficient of determination $\left(\mathrm{R}^{2}\right)$ of 0.15 (Fig 4). Then, regression analysis was undertaken among the five surplus production models to determine the best fit model, as shown in Table 3. Statistically, Walter and Hilborn, Fox, and the CYP model produced a more significant coefficient of determination $\left(\mathrm{R}^{2} \geq 0.44\right)$. However, those models generated inappropriate coefficient variables indicated by positive value for slopes (effort) led to unrealistic values of the estimated optimum catch and effort. Therefore, the Schnute model was selected as the best fit model to estimate biological parameters $\left(\mathrm{R}^{2}=0.39\right)$. Some biological parameters such as intrinsic growth rate $(\mathrm{r})$, catchability coefficient $(\mathrm{q})$, and carrying capacity $(\mathrm{K})$ were estimated at 1.154 tons per year, $1.6 \times 10^{-5}$ tons per unit, and 50,843 tons per year, respectively.

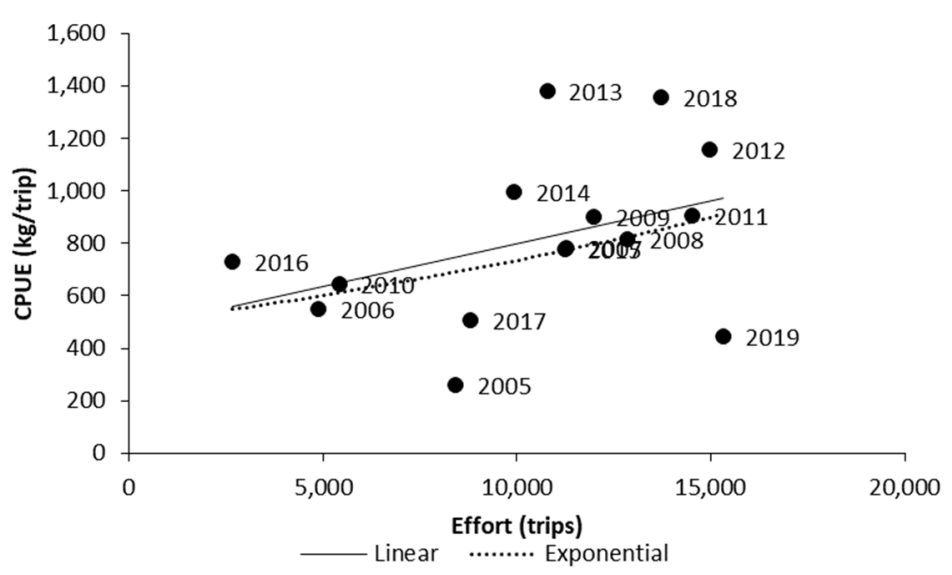

Fig. 4. The relationship between CPUE and standardized-fishing effort from 2005 to 2019 expressed in the exponential and linear equation. 
Table 3. Statistical results of the regression relationship between CPUE and effort estimated using various models of surplus production.

\begin{tabular}{|c|c|c|c|c|c|}
\hline \multirow{2}{*}{$\begin{array}{c}\text { Statistical } \\
\text { Parameters }\end{array}$} & \multicolumn{3}{|c|}{ Logistic } & \multicolumn{2}{|c|}{ Exponential } \\
\hline & Schaefer & Schnute & WH & Fox & CYP \\
\hline \multicolumn{6}{|c|}{ Regression statistics } \\
\hline $\mathrm{R}^{2}$ & 0.29 & 0.39 & 0.52 & 0.44 & 0.44 \\
\hline Observation & 13 & 14 & 14 & 13 & 14 \\
\hline Intercept & 0.36 & 0.46 & 1.17 & 4.65 & 6.88 \\
\hline $\mathrm{X}_{1}$ (CPUE) & 0.0006 & -0.0003 & -0.001 & -0.74 & -0.12 \\
\hline $\mathrm{X}_{2}$ (Effort) & -0.00003 & -0.00001 & 0.000048 & 0.000038 & 0.000031 \\
\hline \multicolumn{6}{|c|}{$\mathrm{p}$-value } \\
\hline Intercept & 0.18 & 0.01 & 0.009 & 0.02 & 0.0008 \\
\hline $\mathrm{X}_{1}$ (CPUE) & 0.07 & 0.004 & 0.002 & 0.02 & 0.63 \\
\hline $\mathrm{X}_{2}$ (Effort) & 0.24 & 0.64 & 0.23 & 0.1 & 0.14 \\
\hline
\end{tabular}

\subsection{Estimation of fisheries sustainability and bioeconomic}

The Schnute model is applied to estimate the sustainability of the bonito fishery from biological and economic perspectives. Sustainability catches and effort at Maximum Sustainable Yield ( $\mathrm{C}_{\mathrm{MSY}}$ and $\left.\mathrm{E}_{\mathrm{MSY}}\right)$ were estimated at 11,695 tons and 16,767 trips. The sustainability was also estimated according to the economic point of view, namely, Maximum Economic Yield $\left(\mathrm{C}_{\mathrm{MEY}}\right.$ and $\left.\mathrm{E}_{\mathrm{MEY}}\right)$, approximated at 11,428 tons and 14,237 trips, respectively. In these two management conditions, MSY allows higher catches and efforts when compared to MEY conditions. Thus, the revenue and total cost at MSY were greater than MEY. However, it led to lower net profit, as illustrated in Fig. 5. The bioeconomic analysis also provided for the worst situation, namely Open Access $\left(\mathrm{C}_{\mathrm{OA}}\right.$ and $\left.\mathrm{E}_{\mathrm{OA}}\right)$. At this management regime, excessive fishing efforts were occurred uncontrollably, resulting in the lowest quantity of catches and total revenue. On the other hand, it is impacted to the highest fishing cost, so that a lowest net profit was generated at this level (Table 4).

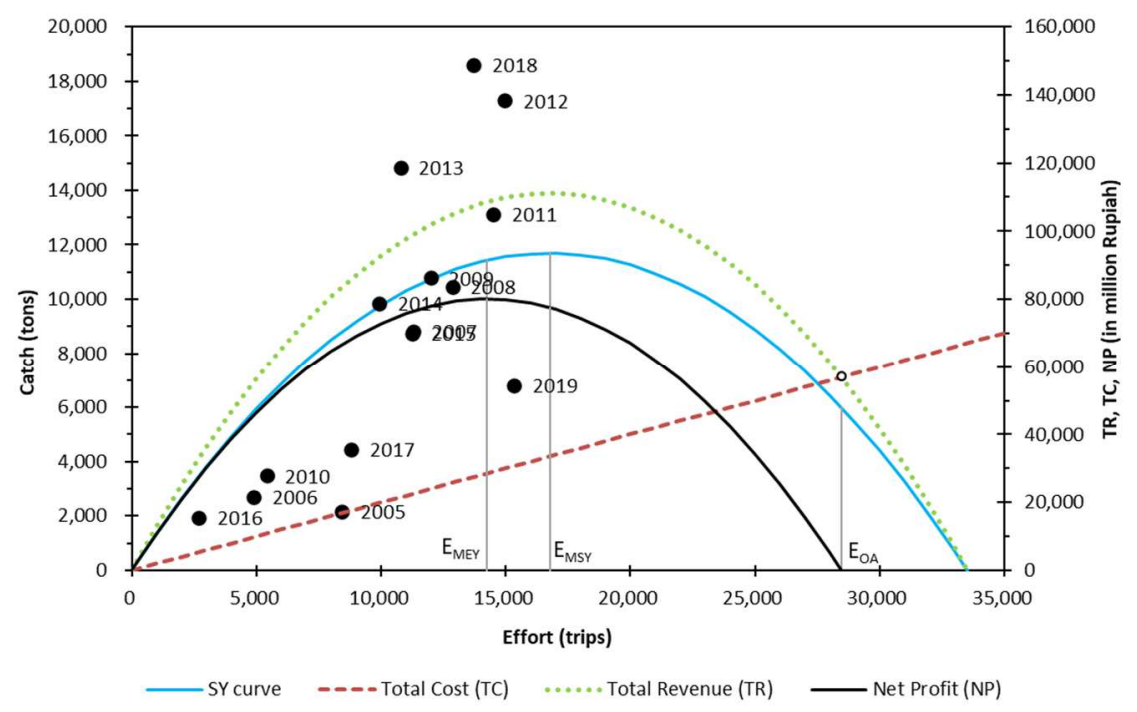

Fig. 5. An illustration of annual catch and effort of bonito compared to the sustainable yield (SY), total revenue (TR), total cost (TC) and net profit (NP) estimated by the Schnute model. 
Table 4. Estimation of fisheries sustainability using bioeconomy analysis at three conditions of management (MSY, MEY, and OA)

\begin{tabular}{|l|r|r|r|r|}
\hline \multirow{2}{*}{$\begin{array}{c}\text { Fisheries sustainability } \\
\text { variables }\end{array}$} & \multirow{2}{*}{$\begin{array}{c}\text { Actual average } \\
(2015-2019)\end{array}$} & \multicolumn{3}{|c|}{ Management conditions } \\
\cline { 3 - 5 } & 9,984 & 11,695 & 11,428 & \multicolumn{1}{c|}{ OA } \\
\hline Catch (tons) & 10,354 & 16,767 & 14,237 & 28,473 \\
\hline Fishing effort (trips) & 20,708 & 33,534 & 28,473 & 56,946 \\
\hline Total cost/TC (mill Rp) & 94,852 & 111,104 & 108,574 & 56,946 \\
\hline Total revenue/TR (mill Rp) & 74,144 & 77,570 & 80,100 & 0 \\
\hline Net profit (mill Rp) & &
\end{tabular}

\section{Discussion}

This study underlined that the purse seine was an adequate fishing gear to catch bonitos that are commonly found in large schooling. The use of one-pair purse seine was widely found in the coastal area of southern East Java and the Bali Strait. The first boat was acted as a hunter boat with a tower where fishing masters worked in finding a school of fishes. Meanwhile, another boat was used to carry the catch and equipped with many baskets. Technically, the Prigi-based mini purse seiner can be categorized as the small pelagic purse seiner, as a narrow mesh size was observed. Hence, it is also suitable for targetting small pelagic fishes such as sardines (Sardinella spp.), scad (Decapterus spp.), mackerel (Rastrelliger spp.) [16]. Compared to the Regulation of Minister of Marine Affairs and Fisheries Number 18/2021 related to the placement of fishing gears and tools, small pelagic-purse seines based in Prigi generally do not meet the rule. Therefore, monitoring and surveillance are needed about the compliance of fishing gear used to improve the catch's selectivity.

Our findings also highlighted that the CPUE was varied inter-annually. The changes of CPUE were affected by upwelling intensity that corresponds to climate variability such as El Nino Southern Oscillation or ENSO (El-Nino and La Nina) and Indian Ocean Dipole or IOD (positive and negative) period and [29]. For instance, the CPUE peaked in 2018, which coincided with the El-Nino phenomenon, and IOD positive has occurred. Periods of El Niño and IOD positive lead to a high chlorophyll-a concentration and are followed by a decrease in Sea surface temperature [30]. Thus, the waters become rich in nutrients and causing an increase in the catch of pelagic fish [31-32]. In contrast, low CPUE occurred in 2010 and 2017, along with the La-Nina phenomenon. In this period, chlorophyll-a concentrations were down, and sea surface temperatures increased due to a high frequency of rain, which also decreased the salinity levels due to an increased flow of fresh water from upstream [33].

The CPUE pattern also was varied monthly. Given that the CPUE is essential information to estimate the index of fish abundance [34], it also can be used to estimate the seasonal abundance as described as an index. The variation in time and duration of the abundant season is influenced by the condition of the waters in terms of providing food nutrients. These were also related to the periodicity of upwelling events throughout the year. Upwelling on the south coast of Java developed in April and moved westwards. Then, it weakened in November as it entered the south coast of West Java [35].

As the CPUE is also used as the proxy to represent fish abundance, the decreasing trend of CPUE during the last decade indicates that the stock size is declining. Despite an overfished and overfishing has not occurred, indicated by the average catches and efforts during 2014-2019 was lower than $\mathrm{C}_{\mathrm{MSY}}$ and $\mathrm{E}_{\mathrm{MSY}}$ (Table 4). However, the fishing effort of $2019\left(\mathrm{E}_{2019}\right)$ has exceeded that at $\mathrm{E}_{\mathrm{MEY}}$, as illustrated in Fig. 5. Consequently, the expenditure for fishing cost at $\mathrm{E}_{2019}$ was higher generates a low net profit due to the excessive fishing efforts. Thus, these are alarming that the economic overfishing has occurred for the bonito fisheries in the Prigi and surrounding waters. 
Management measures such as reducing fishing efforts are suggested as the precautionary approach. The port authority can initiate it by a moratorium program for new vessel licenses. It is worth underlining that reducing the effort or maintaining the status quo level of 2018 $\left(\mathrm{E}_{2018}\right)$ can be more advantageous to keep the stock and generate optimum economic profits. The management measure also needs to be accompanied by improving the compliance level toward the regulations related to the use of fishing gear. The understanding to let small fish shall not be caught urgently needs to be echoed to fishers and beneficial in the long run for business continuity. In other words, excessive utilization impacts the increase in total cost, which has consequences on the decrease in net profit. If uncontrolled fishing continues, it will lead to the regime of open access-fisheries. It was no longer profitable from a business perspective, and all invested capital are dissipated.

\section{References}

1. B. B. Collette, C. R. Aadland, Fish. Bull. 94, 423-441 (1996)

2. Y. Tao, M. Chen, J. Du, Z. Lu and Y. Shengyun, Lat. Am. J. Aquat. Res. 40, 649-656 (2012)

3. IOTC-WPDCS06, Paper presented on the $6^{\text {th }}$ session of IOTC Working Party on Data Collection and Statistic (IOTC, Victoria, Seychelles, 2009)

4. J. J. Maguire, M. Sissenwine, J. Csirke, R. Grainger, S. Garcia, The State of World Highly Migratory, Straddling and Other High Seas Fishery Resources and Associated Species (FAO, Rome, 2006)

5. B. B. Collette, C. E. Nauen. FAO species catalogue vol. II scombrids of the world: an annotated and illustrated catalogue of tunas, mackerels, bonitos and related species known to date (FAO, Rome, 1983)

6. IOTC-WPNT10, Report of the $10^{\text {th }}$ Session of the IOTC Working Party on Neritic Tunas (IOTC, Victoria, Seychelles, 2020)

7. N. Zulbainarni, Theory and Practice of Bioeconomic Modelling in Capture Fisheries Management (IPB Press, Indonesia, 2012)

8. L. G. Anderson, S. J. Carlos, Bio-economics of Fisheries Management (WilleyBlackwell, Oxford, 2010)

9. A. Fauzi, Fisheries Economic: Theory, Policy, and Management (PT. Gramedia Pustaka Utama, Jakarta, 2010)

10. C. W. Clark, Bioeconomic Modelling of Fisheries Management (J. Wiley \& Sons, New York, 1985)

11. A. Fauzi, Natural Resource Economics and the Environment: Theory and Application (PT. Gramedia Pustaka Utama, Jakarta, 2004)

12. A. Fauzi, S. Anna, Fisheries and Marine Resources Modelling for Policy Analysis (PT. Gramedia Pustaka Utama, Jakarta, 2005)

13. A. Setiyawan, S. T. Haryuni, Wijopriono (in Bahasa Indonesia), Depik J. Ilmu-Ilmu Perair. Pesisir Perik. 2, 7-11 (2013)

14. Suhana, T. Kusumastanto, L. Adrianto, A. Fahrudin (in Bahasa Indonesia), J. Sosek KP 14, 23-36 (2019)

15. H. Ilhamdi, R. Telussa, D. Ernaningsih (in Bahasa Indonesia), J. Ilmiah Sat. M. Bahari 1, 52-64 (2016)

16. Suwarso, A. Wujdi, M. Fauzi, Indones. Fish. Res. J. 20, 69-76 (2014)

17. Pelabuhan Perikanan Nusantara Prigi, Statistic Report 2018 of Prigi Archipelagic Fishing Port (in Bahasa Indonesia) (KKP, Jakarta, 2019) 
18. Pelabuhan Perikanan Nusantara Prigi, Statistic Report 2019 of Prigi Archipelagic Fishing Port (In Bahasa Indonesia) (KKP, Jakarta, 2020)

19. M. King, Fisheries Biology, Assessment, and Management (Fishing News Books, Oxford, 1995)

20. P. Sparre, S. C. Venema, Introduction to Tropical Fisheries Stock Assessment, Part I: Manual (FAO, Rome, 1998)

21. M. R. Spiegel, Theory and Problems of Statistics (Schaum Publishing Co., New York, 1961)

22. S. Pascoe, Bioeconomic Models and Modelling: Theory and Practice (CEMAREUniversity of Portsmouth, Portsmouth, 1995).

23. M. B. Schaefer, Inter-Am. Trop. Tun. Comm. Bull. 1, 23-56 (1954)

24. W. W. Fox, Trans. Am. Fish. Soc. 99, 80-88 (1970)

25. J. Schnute, J. Fish. Res. Bd. Canada 34, 584-603 (1977)

26. R. P. Clarke, S. S Yoshimoto, and S.G. Pooley, Mar. Resour. Econ. 7, 115-140 (1992)

27. F. J. Richard, J. Exp. Bio. 10, 290-300 (1959)

28. E. M. Thunberg, T. E. Helser, R. K. Mayo, Mar. Resour. Econ. 13, 51-74 (1998)

29. N. Hendiarti, H. Siegel, T. Ohde, Deep-Sea Res. Part II-Top. Stud. In Oceanogr. 5, 8597 (2004)

30. A. Wijaya, U. Zakiyah, A. B. Sambah, and D. Setyohadi, Biodiversitas 21, 5283-5290 (2020)

31. A. P. Prasetyo, Suwarso, J. Tek. Man. Perik. Laut 1, 159-168 (2010)

32. N. Hendiarti, Suwarso, E. Aldrian, K. Amri, R. Andiastuti, S. I. Sachoemar, I. B. Wahyono, Oceanography 18, 112-123 (2005)

33. Kunarso, S. Hadi, N.S. Ningsih, M. S. Baskoro, IJMS 16, 171-180 (2011)

34. R. A. Campbell, Fish. Res. 70, 209-227 (2004)

35. H. I. Ratnawati, R. Hidayat, A. Bey, T. June, Omni-Akuat. 12, 119-130 (2016) 